\title{
Temperature Profiles in Forced-Ventilation Enclosure Fires
}

\author{
JANA BACKOVSKY, KENNETH L. FOOTE, and NORMAN J. ALVARES \\ Lawrence Livermore National Laboratory \\ P.O. Box 5505, L-442 \\ Livermore, California 94550, USA
}

\section{ABSTRACT}

We investigated the effect of ventilation rate, ventilation configuration, fire elevation, and the presence of a plenum (suspended ceiling) on the fire compartment temperatures during forced ventilated methane gas fires $(100-400 \mathrm{~kW})$. We found that with low air-inlet positions, fires with ventilation rates greater than $2-3$ times the stoichiometrically requixed air (referred to here as well-ventilated fires) produce twolayer temperature profiles; fires with a lower ventilation rate (underventilated fires) produce single-layer profiles with a temperature gradient. Higher temperatures throughout the enclosure are seen in underventilated fixes as compared to well-ventilated fires. We observed that high air-inlet locations perturb the two-layer temperature profile of the well-ventilated fire, cooling the upper layer and heating the lower layer. For underventilated fires, high air-inlet locations lower temperatures in the enclosure but do not perturb the profile shape. Elevated fires and fires in a compartment with a plenum were seen to behave similarly for the same distance from fire base to ceiling, producing hotter layers the shorter the distance.

\section{INTRODUCTION}

The temperatures throughout an enclosure in which a fire is burning are affected by the amount of air supplied to the fire and the location where the air enters the enclosure. Underventilated fires produce different temperature profiles in an enclosure than well-ventilated fires. Such behavior has been observed for naturally ventilated fires by orloff et al. (1978) and discussed by Drysdale (1985). However, little work has been done with forced ventilation fires.

Since 1981, a program to investigate forced-ventilation fires has been conducted using the Fire Test Cell at Lawrence Livermore National Laboratory (LLNL). The early experiments (Hasegawa et al., 1983) used a variety of fuels, ventilation rates, and fire strengths (heat release rates). Most of these fires were analog pool fires in which gas fuel was metered into a burner. The main findings were as follows: $80 \pm 5 \%$ of the heat produced in the fire was deposited in the enclosure walls; "quasisteady state" was not reached until about $2000 \mathrm{~s}$ (seconds) after Ignition; and twice the stoichiometrically required ventilation was needed to ensure complete combustion of the fuel in a low-inlet, forced-ventilation 
geometry. Eurther tests (Alvares et al., 1984) confirmed and refined these observations, providing data that was used to develop a temperature correlation for forced-ventilation compartment fires (Foote et al., 1986) and to test and compare avaiiable computer fire models (Hasegawa et al., 1984, and $\operatorname{cox}$ et al., 1986).

This paper is based on the 1986 series of 64 tests in which the effects of ventilation rate, ventilation configuration, fire elevation, and enclosure geometry were examined using methane gas fires. The fire behavior is found to be sensitive to the air inlet location (see Figure 1). For low inlet locations, complete combustion in quasi-steady state is observed for ventilation rates above 1.5 times the stoichiometrically required air, incomplete combustion below this ventilation rate, and extinction when the ventilation rate is less than the stoichiometric value. For high air-inlet locations, complete combustion in quasi-steady state is observed when the ventilation rate is at least 4 times the stoichiometric value, but extinction occurs when the ventilation rate is less than 4 times the stoichiometric value. The results presented here are some of the measured vertical temperature profiles. For a complete description of the 1986 test series and the data obtained, see Foote (1988). The data will be used in improving the modeling of forcedventilation fires.

\section{EXPERIMENTAL SETUP}

In Figure 1, we present a schematic of the $100-\mathrm{m}^{3}(4 \times 6 \times 4.5 \mathrm{~m})$ LLNL Fire Test Cell facility (Alvares et al., 1984), showing the air inlet and exhaust locations and the plenum (when used). Figure 2 shows the floor plan of the facility, with some of its instrumentation.

Methane gas is delivered to a $23-\mathrm{cm}$ tall, $52-\mathrm{cm}$-diametex burner filled with small rocks. The burner has a $8-\mathrm{cm}$ lip and thus the burner surface is $15 \mathrm{~cm}$ above the floor in the center of the room. The $30-\mathrm{cm}-$ diameter air inlet duct delivers air at a height of $30 \mathrm{~cm}$ above the floor

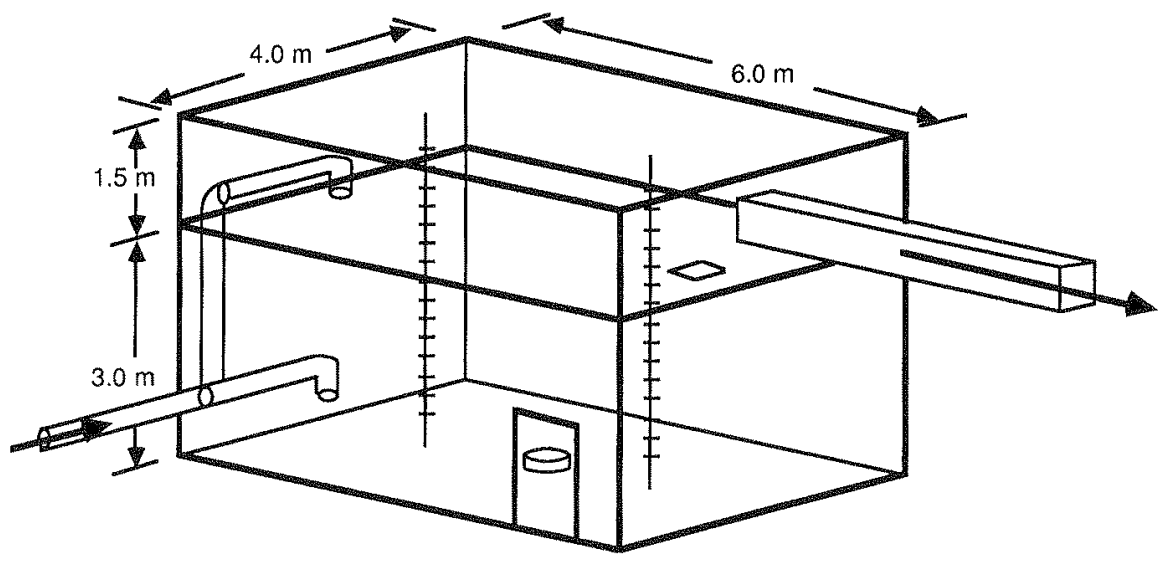

Figure 1. Schematic diagram of the LINL Fire Test Cel1. 


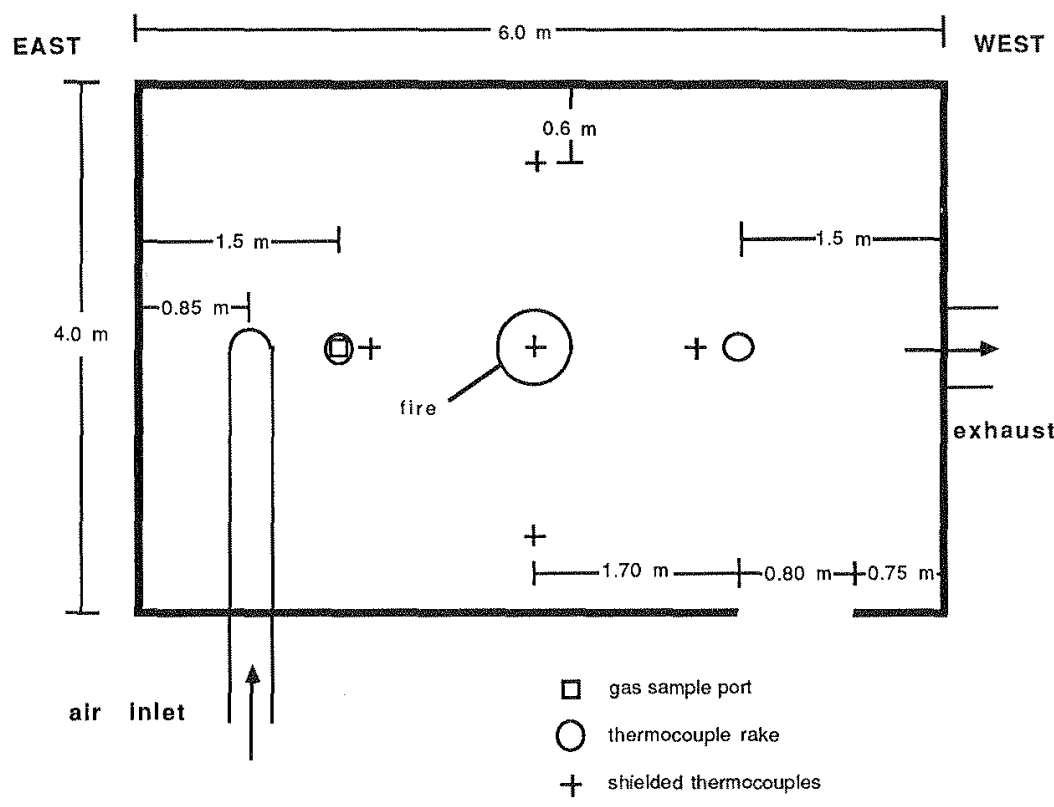

Eigure 2. Floor plan of LLNL Fire Test Cell showing instrumentation.

near the east wall, with the airflow directed downward toward the floor. In experiments with a high air-inlet location, the inlet duct delivers air at $3-\mathrm{m}$ height, flush with the bottom surface of the plenum partition and pointing downward. The center of the $65 \mathrm{x} 65 \mathrm{~cm}$ exhaust duct is at a height of $3.6 \mathrm{~m}$. When forced ventilation is not used, the inlet duct remains open, but the exhaust duct is effectively sealed by the fan and no flow of hot air occurs in the exhaust duct. Figures 1 and 2 show the $0.8 \times 2-m$ door which is used for natural ventilation.

The walls and ceiling of the Fire Test cell are 10-cm-thick aluminum silicate refractory brick with properties as follows: thermal conductivity, $0.463 \mathrm{~W} / \mathrm{m}-\mathrm{K}$; density, $1607 \mathrm{~kg} / \mathrm{m}^{3}$; and specific heat $1.0 \mathrm{~kJ} / \mathrm{kg}-\mathrm{K}$. In several tests a plenum made of 2.5-cm-thick Marinite was installed at $3-\mathrm{m}$ height, giving a plenum space $1.5 \mathrm{~m}$ high. The plenum has a $40 \mathrm{x} 40-\mathrm{cm}$ opening under the exhaust duct location, as shown in Figure 1. The material properties of the plenum are as follows: thermal conductivity, 0.12 $\mathrm{W} / \mathrm{m}-\mathrm{K}$; density, $700 \mathrm{~kg} / \mathrm{m}^{3}$; and specific heat, $0.10 \mathrm{~kJ} / \mathrm{kg}-\mathrm{K}$.

There are two thermocouple rakes in the room, located $1.5 \mathrm{~m}$ in from the east and west walls (see Figure 1). Each rake contains 15 vertically aligned 0.004-in. chromel-alumel thermocouples spaced $30 \mathrm{~cm}$ apart. The bottom thermocouple is $15 \mathrm{~cm}$ above the floor and the top thermocouple is $15 \mathrm{~cm}$ below the ceiling. The temperatures reported here are those actually measured at the west rake (i.e., they are not averaged). Despite turbulence, the shape of these profiles is essentially invariant after 


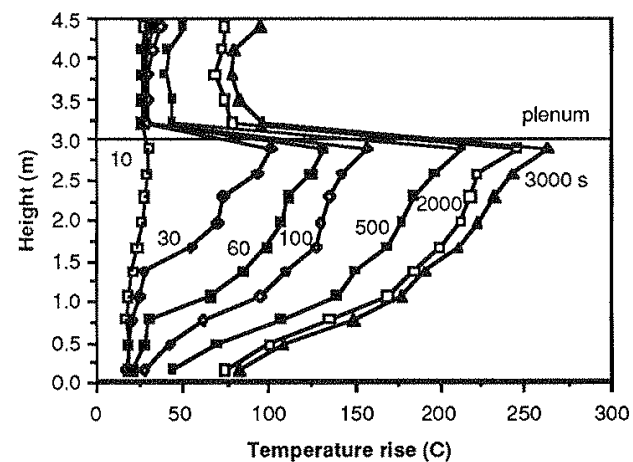

Figure 3. Temperature profile development for an underventilated fire. Times shown (in seconds) are from the start of the fire $(200-\mathrm{kW}$ fire with $100-\mathrm{g} / \mathrm{s}$ forced ventilation).

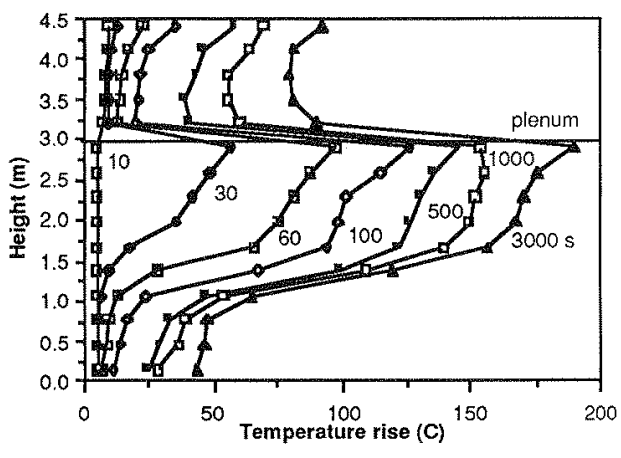

Figure 4. Temperature profile development for a well-ventilated fire. Times shown (in seconds) are from the start of the fire $(200-\mathrm{kw}$ fire with $500-\mathrm{g} / \mathrm{s}$ forced ventilation).

$1000 \mathrm{~s}$. Measured temperatures in the enclosure vary due to turbulent fluctuations, which range from very low values $( \pm 5 \mathrm{C})$ in the cool layer and plenum space to highest values in the ceiling jet region $( \pm 15 \mathrm{C})$ and the interface region $(+20 \mathrm{c})$. The temperature fluctuations in and near the interface region include effects of gravity waves and turbulence. The high-inlet location produces local temperature fluctuations of up to $\pm 15 \mathrm{C}$ within $1 \mathrm{~m}$ of the air inlet. In spite of the moderate turbulent fluctuations in the enclosure, the characteristic shape of the temperature profiles presented in this paper is easily reproducible from test to test.

\section{RES U L T S}

\section{Layer Development}

We distinguish two ways that temperatures in the fire enclosure evolve as a function of time: "one-layer" or "two-layer" profiles. The one-layer case refers to fires that produce only one layer, typically having a vertical temperature gradient throughout. The one-layer case is observed for fires with forced ventilation rates at or below 2 - 3 times the stoichiometrically required air. In this paper, we refer to fires with such a ventilation rate as underventilated fires. An example of how these vertical temperature profiles develop is shown in Figure 3 , which represents a 200-kW fire in an elclosure with a plenum and a ventilation rate of $100 \mathrm{~g} / \mathrm{s}$ (2 times stoichiometric) in the low-inlet configuration. In Figure 3 , the hot layer expands to the floor within $100 \mathrm{~s}$ of ignition, and thereafter the shape of the temperature profile does not change appreciably; i.e., temperatures along the rake increase about the same everywhere. The fire plume and the ventilation airflow apparently create enough turbulence to accomplish the observed mixing.

In contrast, in the "two-layer" case this kind of mixing occurs primarily in the hot upper layer. We observe two-layer temperature pro- 


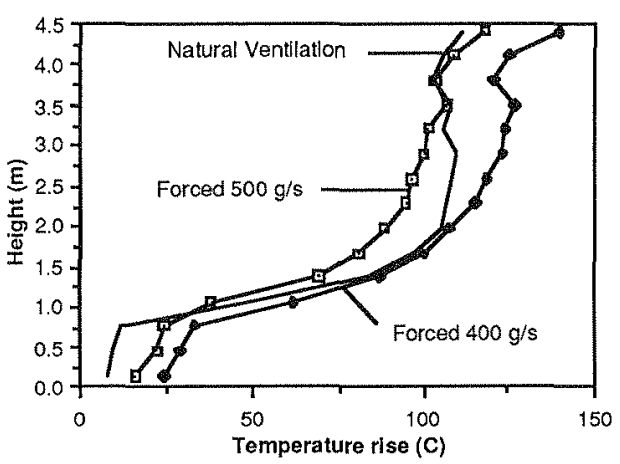

Eigure 5. Temperature profiles Eor well-ventilated $200-\mathrm{kW}$ fires (1000 s after ignition).

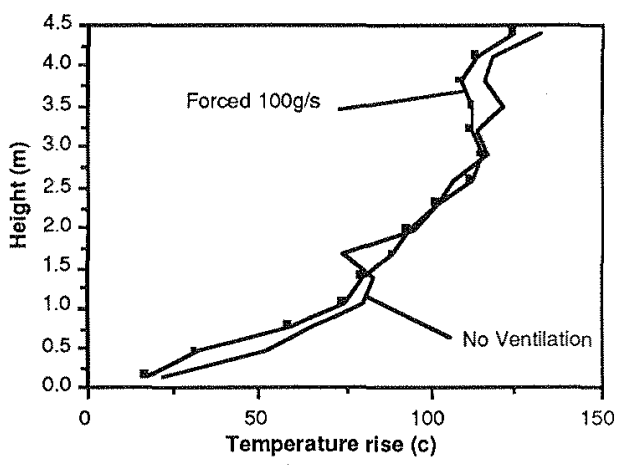

Figure 6. Temperature profiles for underventilated $200-\mathrm{kW}$ fires (500 s after ignition).

files when ventilation rates are higher than 2 - 3 times stoichiometric. We will refer to such fires here as well ventilated. The hot and cool layers are not necessarily isothermal. They can have a moderate temperature variation or even a moderate vertical temperature gradient. We define a two-layer profile as one having an interface region where there is a steep temperature gradient vertically in the enclosure. Figure 4 shows this two-layer temperature profile development for a well-ventilated fire (200 kw, $500 \mathrm{~g} / \mathrm{s}$ air, low inlet location) with a plenum. This two-layer temperature profile develops within $30 \mathrm{~s}$ of ignition. There is little mixing evident between the uppex and the lower layers and the layer interface, identified by the steep temperature gradient, stabilizes between 1.1 and $1.4 \mathrm{~m}$ after $100 \mathrm{~s}$. Unless otherwise stated, all figures after Figure 4 give the temperature rise above ambient at $1000 \mathrm{~s}$ after fire ignition, well after the layers are established.

\section{Ventilation Rate Effects}

Figure 5 shows temperature profiles of three well-ventilated fires with two-layer profiles. Two of the profiles are for forced-ventilation $200-\mathrm{kW}$ fires with airflow rates of 500 and $400 \mathrm{~g} / \mathrm{s}(10$ and 8 times the stoichiometrically required air, respectively); the third profile is for a $200-\mathrm{kW}$ fire naturally ventilated through a $0.8 \times 2-\mathrm{m}$ open door. The naturally ventilated fire has a temperature profile similar to the forced-ventilation fires, but its layers are more nearly isothermal. There is an interface region for all three fires at a height of about 1 to $1.5 \mathrm{~m}$.

Figure 6 shows examples of one-layer temperature profiles of underventilated fires. The figure shows a $200-\mathrm{kW}$ forced-ventilation fire $(100$ $\mathrm{g} / \mathrm{s}$ air or 2 times stoichiometric) and a $200-\mathrm{kW}$ "no-ventilation" fire in which the enclosure was unvented except for the air inlet duct in the Lower part of the room, which served to relieve fire-generated pressure. The hot layer extends essentially all the way to the floor in these tests. Orloff et al. (1978) also observed this effect when the door width was reduced in naturally ventilated fires. The profiles shown in Figure 6 are at $500 \mathrm{~s}$ instead of $1000 \mathrm{~s}$ because the no-ventilation fire 
When the volume of the enclosure and the initial, resident air are reduced by a plenum, the role of the ventilation rate is even greater. Figure 7 shows temperatures for a $200-\mathrm{kw}$ fire with ventilation rates of $100,200,400$, and $500 \mathrm{~g} / \mathrm{s}(2,4,8$, and 10 times the stoichiometric aix required). The $500 \mathrm{~g} / \mathrm{s}$ ventilation rate produces a distinct two-layer. temperature profile, with most of the hot layer being nearly isothermal. in this case. As the ventilation rate is reduced $(400$ and $200 \mathrm{~g} / \mathrm{s})$ the layer interface is increasingly lower. The $100-9 / \mathrm{s}$ ventilation rate produces higher temperatures everywhere in the enclosure and has a one-layer profile with an almost uniform temperature gradient from floor to ceilin $g$.

For cases with low-inlet position, the layer height stabilizes at a height such that the total mass flux of the plume gases entering the hot layer at the interface equals the mass flux of the gases leaving the layer by ventilation exhaust. The layer height is observed to stabilize at a level consistant with the findings of cetegen et a1.(1982). The layer interface calculated by assuming the equality of the above mass fluxes (using cetegen's formula for the total plume mass flux) is within $12 \%$ of our "measured" interface heights. The "measured" interface height is taken as the midpoint between the two adjacent themocouples spanning the greatest rise in temperature. This is consistent with the definition of the interface region as the region of steepest temperature rise.

\section{Ventilation Configuration Effects}

We examined the differences in temperature caused by changing the air inlet location from low in the room to high in the room. In the "low inlet" case, the air is delivered in the lower part of the compartment on the east side of the room and ejected toward the floor. In the "high inlet" case, the air enters the compartment at 3-m height and is discharged downward at the level of the plenum from a $30-\mathrm{cm}$-diameter duct. The hor-

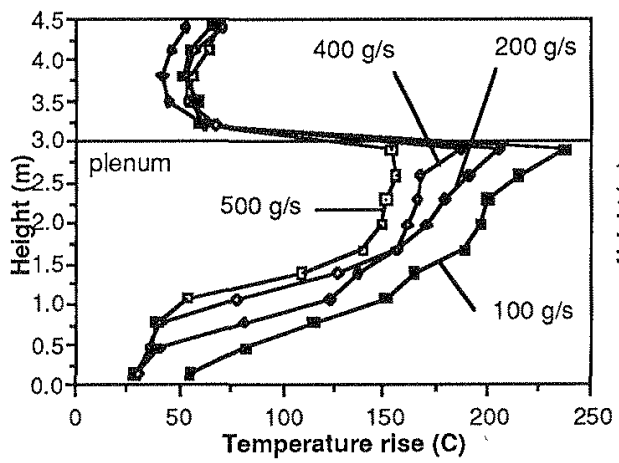

Figure 7. Temperature changes caused by reduced ventilation $(200-$ $\mathrm{kW}$ fire in an enclosure with a plenum).

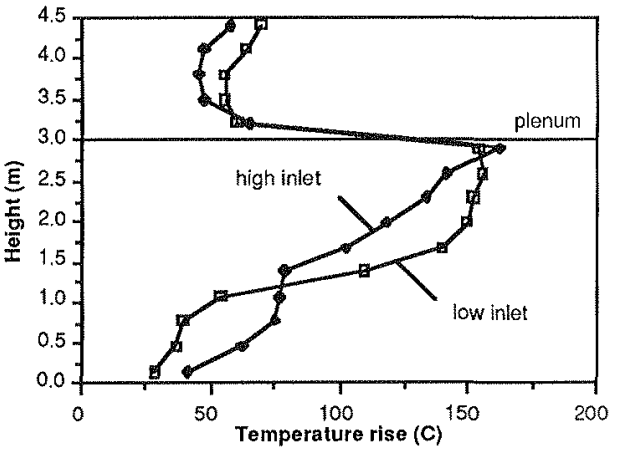

Figuxe 8. High air inlet cools the upper layer but contaminates the lower layer with hot smoke $(200-\mathrm{kW}$ fire with $500-\mathrm{g} / \mathrm{s}$ air). 
izontal location of the high air-inlet duct is the same as that of the low air-inlet duct (see Eigures 1 and 2).

Figure 8 shows that the low-inlet and high-inlet configurations can produce distinctly different temperature profiles. The biggest difference is observed at high ventilation rates $(500 \mathrm{~g} / \mathrm{s}$, or 10 times the stoichiometric air for the $200-\mathrm{kW}$ fire). With the low air-inlet location the typical two-layer profile is obtained. For the high inlet the temperature profile loses some of its two-layer character. The lower layer is heated and the uppex layer is cooled, thus renucing the difference between them. For the case shown in Figure 8, the lower layer is $35-40 \mathrm{C}$ hotter. The maximum temperatures, obtained near the ceiling, differ little in the two cases. Therefore, although the high inlet configuration reduces most of the upper layer temperatures, it does not protect the ceiling. For an air inlet located right above a fire, however, the maximum temperatures may be reduced.

Figure 9 shows that at both high and low ventilation rates the temperature profile is significantly affected by the location of the cold air discharge into the room. For a well-ventilated fire (e.g., $500 \mathrm{~g} / \mathrm{s}$ in Figure 9), a two-layer profile is obtained with the low air-inlet position, but the profile for the high inlet position is perturbed similar to that in Figure 8, and essentially loses the two-layer character. For an underventilated fire (e.g., $100 \mathrm{~g} / \mathrm{s}$ or 2 times stoichiometric in Figure 9), we observe a one-layer temperature profile for both inlet locations; however, the high inlet configuration results in a generally cooler layer. Therefore, both the ventilation rate and the ventilation configuration are seen to be important in determining the temperature profile in the enclosure.

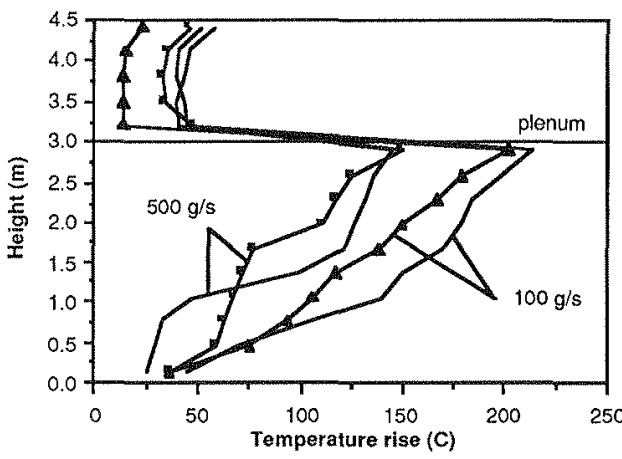

Figure 9. Reduced ventilation elevates temperatures throughout an enclosure regardless of ventilation configuration $(200-\mathrm{kW}$ fire at $500 \mathrm{~s}$, no symbols correspond to low airinlet location and symbols are for high air-inlet location).

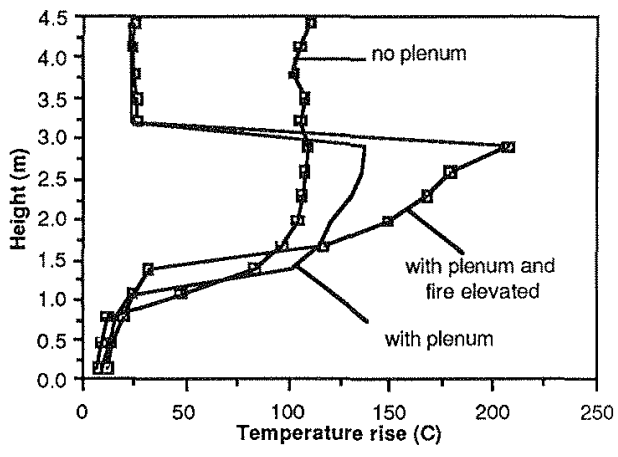

Figure 10. The fire with the shortest distance to the ceiling produces the hottest ceiling layer (200-kW naturally ventilated fires). 


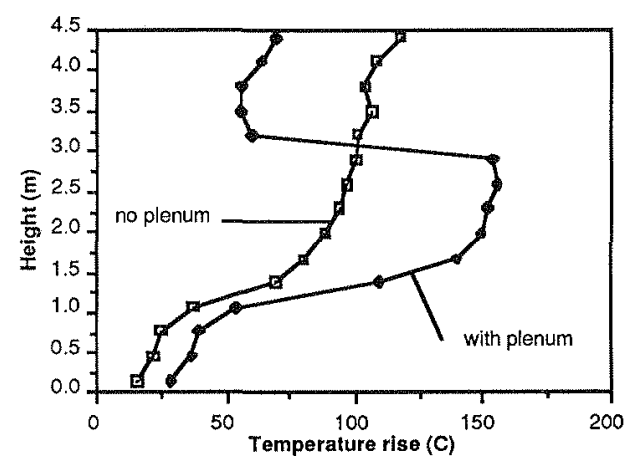

Figure 11. Plenums make upper layers hottex $200-\mathrm{kW}$ fire with $500-$ $g / s$ air).

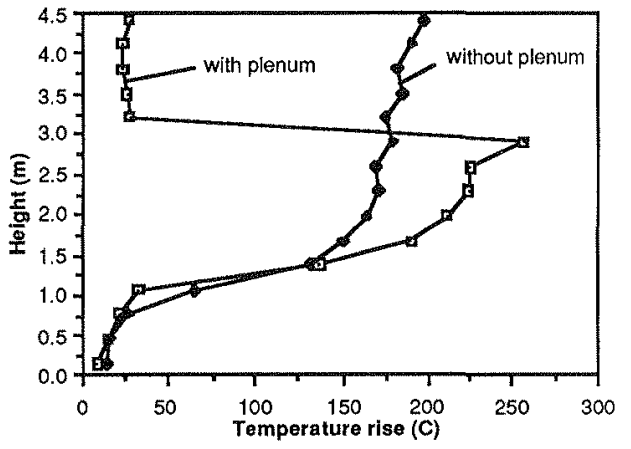

Figure 12, Plenums make uppex layers hotter $(400-\mathrm{kW}$ fire with natural ventilation).

\section{Elevated Fires and suspended Ceilings}

Elevated fires and fires in rooms with suspended ceilings (plenums) produce similar temperature profiles in an enclosure. The distance between the fuel bed and the enclosure ceiling is recognized as important in determining layer temperatures (Cetegen et al., 1982). As this distance is reduced, the plume height is shortened and there is less entrainment of cold air into the plume, thus increasing the upper-layer temperature. The fire with the shortest distance to the ceiling yields the hottest upper layer. Figure 10 shows this by the example of three naturally ventilated fires, and the behavior is similar for forcedventilation fires. In Eigure 10, the distance to the ceiling varies from the high value of $4.3 \mathrm{~m}$ for the full enclosure to $2.1 \mathrm{~m}$ for an elevated fire in the enclosure with a plenum. The elevated fire with the plenum has an upper layer temperature $25 \mathrm{C}$ hotter then the non-elevated fire.

whe figure also shows that for the cases with the shorter plume the layer is thinner.

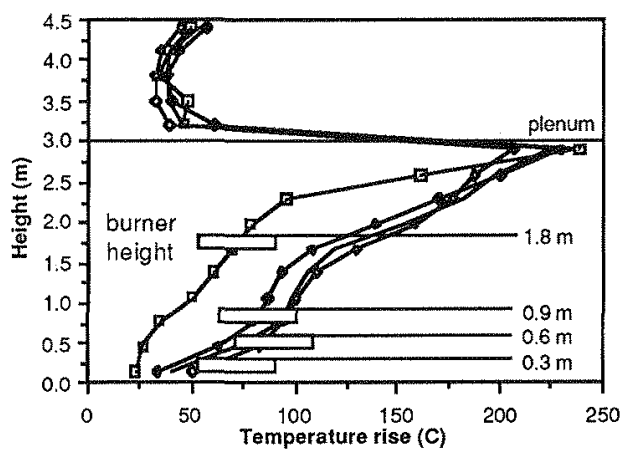

Figure 13. Effect of fire elevation for underventilated fires (200$\mathrm{kW}$ Eire with $180 \mathrm{-g} / \mathrm{s}$ air, $900 \mathrm{~s}$ after ignition). Depending on the particular real-life criteria, an elevated fire may reduce or increase the hazard from fire.

Figure 11 shows a typical difference in temperature profiles with presence of a plenum. Because the fire $(200 \mathrm{kw})$ is well ventilated $1500 \mathrm{~g} / \mathrm{s}$, or 10 times the stoichiometric air), there is an identifiable two-layer profile. The height of the layer interface (1 to $1.5 \mathrm{~m}$ in the near steady state) does not change appreciably with the reduction in room height, but the upper layer becomes significantiy hotter. Figure 12 shows analogous be- 
havior for a naturally ventilated 400-kW fire: plenums make the hot layer hotter, but generally preserve the layer height.

Some behavior of elevated fires was previously known (Cetegen et a1., 1982). We were interested in how fire elevation changes the behavior of underventilated fires when the aix inlet is located high. Figure 13 shows temperatures for four different elevations of otherwise identical fires $(200 \mathrm{~kW}, 180 \mathrm{~g} / \mathrm{s}$ air or 3.6 times the stoichiometric air required, and high air-inlet location). The top of the methane burner was at heights of $0.30,0.60,0.90$, and $1.80 \mathrm{~m}$. For the fire at $1.8 \mathrm{~m}$ elevation, there is a reduction of the temperatures (by 50-60 c) in most of the enclosure. There is a thin, hot upper layer with a steep temperature gradient and a 2.5-m-thick lower layer that also has a temperature gradient. The temperature profiles shown were observed at $900 \mathrm{~s}$ after ignition. These fires are underventilated (less than 4 times stoichiometrically required $a i r)$ and eventually self-extinguish. The higher elevation fire burned longer before self-extinguishment.

\section{CONCIUSIONS}

In experiments with forced-ventilation methane gas fires in the ILNL Fire Test Cell, we made the following observations:

1. For low air-inlet positions, fires with ventilation rates greater than 2-3 times the stoichiometrically required air (well-ventilated fires) produce two-layer temperature profiles with a steep interface region; fires with a lower ventilation rate (underventilated fires) produce single-layer temperature profiles with a temperature gradient.

2. For low air-inlet positions, lowering the ventilation rate increases enclosure temperatures.

3. For well-ventilated fires, high air-inlet locations perturb the twolayer temperature profile, cooling the upper layer and heating the lower layer.

4. For underventilated fires, high air-inlet locations lower temperatures in the enclosure but do not perturb the profile shape.

5. Elevated fires and fires in enclosures with plenums behave similarly for the same distance to ceiling, producing hotter layers the shorter the distance.

Work performed under the auspices of the U.S. Department of Energy by Lawrence Iivermore National Laboratory under Contract W-7405-Eng-48.

\section{REFERENCES}

Alvares, N.J., Foote, K.L., and Pagni, P.J., "Forced Ventilated Enclosure Fires", Combustion Science and Technology, vol. 39, pp. 55-81, 1984.

Cetegen, B.M., Zukoski, E.E., and Kubota, T., "Entrainment and Flame Geometry of Fire Plumes", California Institute of Technology, August 1982.

Cox, G., Kumar, S., and Markatos, N.C., "Some Field Model Validation Studies", Proceedings of the First International Symposium on Fire Safety science, 1986. 
Drysdale, D., An Introduction te Eire Dynamics, John wiley and Sons, New York, 1985.

Foote, K.L., Pagni, P.J., and Alvares, N.J., "Temperature Correlations for Forced-Ventilated Compartment Eires", Proceedings of the First International Symposium on Fire Safety Science, 1986.

Foote, K.I., "1986 LLNL Enclosure Fire Tests", Lawrence Livermore National Laboratory, Rept. UCID-21236-88, February 1988 .

Hasegawa, H. K., Alvares, N.J., Lipska-Quinn, A.E., Beason, D.G., Priante, S.J., and Foote, K.I., "Fire protection Research for DoE Facilities: FY82 Year-End Report", Lawrence Livermore National Laboratory, UCRL-53179-82, september 1983.

Hasegawa, H. K., Alvares, N.J., Lipska-Quinn, A.E., Beason, D.G., Foote, K.L., Priante, S.J., and Staggs, K., "Fire Protection Research for DOE Facilities: FY83 Year-End Report", Lawrence Livermore National LaboratorY, Rept. UCRL-53179-83, August 1984.

Orloff, I., Modak, A.T., and Markstein, G.H., "Radiation from Smoke Layers, " in Proceedings of The Seventeenth Symposium (International) on Combustion, p. 1029, 1978. 